\title{
Long-Run Determinants of Nigerian Inflation Rate: ARDL Bounds Testing Approach
}

\author{
MOHAMED R. ABONAZEL ${ }^{1 *}$, FUAD A. AWWAD ${ }^{2}$, KINGDOM NWUJU ${ }^{3}$, ADEWALE F. \\ LUKMAN $^{4}$, IFEOMA B. LEKARA-BAYO ${ }^{3}$, ENEBI Y. ATANU ${ }^{5}$ \\ ${ }^{1}$ Department of Applied Statistics and Econometrics, Faculty of Graduate Studies for Statistical \\ Research, Cairo University, EGYPT \\ ${ }^{2}$ Quantitative Analysis Department, College of Business Administration, King Saud University, \\ Riyadh, SAUDI ARABIA \\ ${ }^{3}$ Department of Mathematics, Rivers State University, Port Harcourt, NIGERIA \\ ${ }^{4}$ Biostatistics and Epidemiology, University of Medical Sciences, Ondo, Ondo State, NIGERIA \\ ${ }^{5}$ Department of Statistics, Federal Polytechnic of Oil and Gas, Bonny Island, Rivers State, NIGERIA
}

\begin{abstract}
Inflation is a problem in all facets of life and all economic entities. The government of any nation is concerned with ensuring that her plans are not frustrated by unpredictable and galloping prices. This paper studies the dynamic causal relationship between inflation rate (measured by consumer price index (CPI)), exchange rate, gross domestic product (GDP), money growth, and oil export in Nigerian during 2005: Q1 to 2019: Q4. The ARDL bounds testing approach and error correction model were used to verify whether there was a long-term relationship between the inflation rate and four determinants (exchange rate, GDP, money growth, and oil export). The results of our study showed that the current inflation CPI, the exchange rate, GDP, and money growth would still affect the next quarter's inflation rate in Nigeria. However, the oil export has no significant effect on the inflation rate. Moreover, we find the long-run cointegration relationship between inflation CPI, the exchange rate, and money. The cointegration relationship will be achieved in a short time (during the next two quarters of the year).
\end{abstract}

Key-Words: - Autoregressive Distributed Lag Model; Cointegration; Error Correction Model; Exchange Rate; Gross Domestic Product; Money Growth; Oil Export; Unit Root Test

Received: April 12, 2021. Revised: October 3, 2021. Accepted: October 22, 2021. Published: November 10, 2021.

\section{Introduction}

Inflation is defined as a sustained increase in the overall price level over time. During periods of high inflation, the domestic currency's value diminishes, negatively affects the economy [1]. Nigeria has a high inflation rate over the last decade, which has resulted in socio-economic implications. In recent times, real income is falling due to the eroded purchasing power of the currency; there is a monotonic reduction in the number of goods and services that a currency unit can purchase. The country's high inflation trend has resulted in increasing demands by workers, especially those in the public civil service sector, to constantly demand an increase in the national minimum wage.

Furthermore, the desire to have savings and investments has greatly declined, which has affected the country's economic growth. Inflation is a challenge that affects all aspects of life and especially the economy. Therefore, it is the government's responsibility to make sure that its plans and daily programs are not negatively affected by the unpredictable and fluctuating prices of goods and services. Every organization needs a stable macro-economic setting devoid of unrepentant price change, resulting in confidently acceptable future prediction and forecasting to enable quality planning. This is also true for an individual as proper planning enables one to strive in an unsteady economy experienced in Nigeria today. All these results to the growing need to sightsee the study of inflation to develop a time-independent and reliable model [2]. Inflation is a word that is very common and familiar to all. However, very few persons have tried to study it in conjunction with the subject matter - macroeconomic studies of inflation and its determining factors and its effect on a growing economy such as the Nigerian economy.

Comparable to most central banks' directive, the stability of goods and services has continued to be one of the essential directives of the Central Bank of Nigeria $(\mathrm{CBN})$. The fast-growing attention in price steadiness originates from the need to uphold overall macroeconomic equilibrium and the fact that 
price stability encourages investment, productivity, and employment. However, notwithstanding numerous government policies and programs in Nigeria, the economy has reliably experienced high inflation with associated consequences on the most susceptible.

For a while, the grounds of Nigerian inflation could be drawn to several studies such as [3, 4], among others. Variations in money supply, credit to the government by banking system, government discrepancy spending, industrial production and food price indices are underscored influencers that contribute to inflationary propensities in Nigeria. The upsurge in government spending supported by the monetization of oil income and credit from the banking system could also be accountable for the growth of the money supply, which (with lagged effect) underwrites inflationary propensities. Growth in the money supply of an economy is another cause of inflation [5]. The growth of supply intensifies significantly, inflation also rises, and deterioration in the monetary growth rate. This shows a strong relationship between the increase in the supply of money and inflation. The increasing cost of goods is frequently taken to be counterproductive and detrimental to an economy. The most noteworthy consequence of inflation is its impact on the incomes and revenue of the government. When inflation is on the increased as well planned previously, the government's revenue will consequently increase. Inflation is also accountable for the inadequacies and onperformance of an economy. It makes budgeting and future planning tough for economic managers. It imposes a slog on efficiency and productivity, predominantly when firms are compelled to shift possessions away from products and services, thereby disheartening investment and hindering growth [6].

\section{Literature Review}

The Autoregressive Distributed Lag (ARDL) model is accepted as a standard least square regression with lags of both independent and dependent variable as regressors $[5,7,8]$. Though the ARDL model has been vastly applied in econometric studies for decades, they have added approval lately as a method of examining cointegration between economic variables as projected by Pesaran and Shin [9] and extended by Pesaran et al. [10]. In economic literature, there have been several cointegration methods. According to Emeka and Kelvin [11], the econometric term of "cointegration" is used to reproduce the reality of a long-run symmetry among economic variables that meets over time and the ARDL method is most preferred as the latest of these cointegration technique used to inspect self-motivated and symmetric relationships between dependent variables and independent variables. For details on cointegration methods, see e.g., $[10,12,13,14,15]$ Recently, Ghouse et al. [16] indicated that the ARDL model can be used as an alternative tool to avoid the spurious regression problem.

One of the advantages of the ARDL model is: it is used to study the long-run cointegration relationship between the mixed-stationarity variables (some of these variables stationarity at level $\mathrm{I}(0)$ and others variables are stationarity at first difference I(1)). This advantage makes the ARDL model flexible for use in many empirical studies. Here are some of these studies.

Ghavam et al. [17] studied the long-run relationship between the inflation rate and its factors in Iran using ARDL approach. Their results mentioned that the GDP, the imported inflation, liquidity and the exchange rate are the most significant factors affecting Iran's inflation. Tian and Ma [18] applied the cointegration ARDL method to investigate the relationship between the exchange rate and the Chinese share market. Chaudhry et al. [19] used the ARDL bounds test approach to study the relativity between foreign exchange reserves and inflation rates in Pakistan between the years 1960 to 2007. Their results showed that there is a long-run cointegrating relationship between the two series. Chou and Tseng [20] also used the ARDL bounds test by considering the time frame from 1982 to 2010 to examine the consequence of oil price volatility on Taiwan's inflation. They discovered that there is a long-run relationship between the global oil prices and the inflation rate in Taiwan.

Many studies focused on the relationship between inflation and other economic variables such as money supply, GDP, and Exchange rate [5, 21]. Since this relationship is contentious and lacks agreement, it is significant to deliberate recent discoveries highlighting some tightfitting trends in the variables as they narrate to inflationary singularity. Considering the old traditional equation, growth in the amount of money will cause a proportional increase in the overall price level. By this, those in charge of funds possess a direct connection between money supply and inflation. This ideology of thought maintains that an increase in the money supply may result from shortfall government expenditure or expansionary debt financing, which may increase the overall price level. 
Here in Nigeria, there have been many research works done by various scholars on the area of money supply and prices. One notable one is the work of Ajayi [22], who examined the relationship between money, prices and interest rates in Nigeria. He determined that money is one of the substantial causes of the growing price level. His discoveries replicated the old-style method, where the relationship between money and prices is presumed to be straight and one way.

Recently, Abonazel and Elnabawy [5] employed the ARDL bounds test approach to study Egypt's inflation rate. They studied the dynamic fundamental relations between inflation rate, foreign exchange rate, money supply, and GDP in Egypt during 2005: Q1 to 2018: Q2. They examined whether a long-run symmetric relationship exists between the inflation rate and three determining macro variables (foreign exchange rate, money supply, and GDP). Their results showed that the exchange rate and the growth in the money supply have noteworthy effects on Egypt's inflation rate. In contrast, the real GDP has no significant consequence on the inflation rate.

\section{Data and Methodology}

According to this background and literature review, this paper studies the dynamic causal relationship between inflation rate, exchange rate, GDP, money growth, and oil export in Nigerian during 2005: Q1 to 2019: Q4.

\subsection{Description of Data}

Data on Nigerian inflation as influenced by economic variables (money supply, real gross domestic product, oil price and exchange rate) were used. The data covering the period 2005 -2019 were obtained from World Bank and Central Bank of Nigeria $(\mathrm{CBN})$.

\subsection{Research Method}

The methodology adopted in this study is the Autoregressive Distributive Lag (ARDL) approach to co-integration testing. The form of $\operatorname{ARDL}(p, q)$ model is expressed as follow:

$$
\begin{aligned}
y_{t}= & \theta+\alpha_{1} y_{t-1}+\cdots+\alpha_{p} y_{t-p}+\beta_{0} x_{t}+ \\
& \beta_{1} x_{t-1}+\cdots+\beta_{q} x_{t-q}+e_{t},
\end{aligned}
$$

where $p$ is a number of lags of $y$ (lag order of $y$ ) and $q$ is a number of lags of $x$ (lag order of $x$ ). We can rewrite (1) as following:

$$
y_{t}=\theta+\sum_{i=1}^{p} \alpha_{i} y_{t-i}+\sum_{i=0}^{q} \beta_{i} x_{t-i}+e_{t}
$$

The previous model assumes that we have one explanatory variable, hence, if we have $k$ explanatory variables, the general $\operatorname{ARDL}\left(p, q_{1}, q_{2}, \ldots, q_{k}\right)$ model is

$$
\begin{gathered}
y_{t}=\theta+\sum_{i=1}^{p} \alpha_{i} y_{t-i}+\sum_{i=0}^{q_{1}} \beta_{i} x_{1 t-i}+\cdots+ \\
\sum_{i=0}^{q_{k}} \gamma_{i} x_{k t-i}+e_{t} .
\end{gathered}
$$

The assumption of $\operatorname{ARDL}\left(p, q_{1}, q_{2}, \ldots, q_{k}\right)$ in (3), can be expressed as following:

1. Linear in parameter.

2. $E\left(e_{t}\right)=0$.

3. $\operatorname{Var}\left(e_{t}\right)=\sigma^{2}$.

4. $\operatorname{Cov}\left(e_{t}, e_{s}\right)=0 ; t \neq s$.

5. $\operatorname{Cov}\left(e_{t}, x_{t l}\right)=0 ; \forall t, l=1,2, \ldots, k$

6. $e_{t}$ is normally distributed.

Because the estimation is straightforward, least squares estimation is an appropriate estimation technique under the mentioned assumptions above [23].

\subsection{Requirements of ARDL Cointegration Testing}

- Irrespective of whether the underlying variables are $\mathrm{I}(0)$ or $\mathrm{I}(1)$ or a combination of both, ARDL technique can be applied. This helps to avoid the pretesting problems associated with standard co-integration analysis which requires the classification of the variables into $\mathrm{I}(0)$ and $\mathrm{I}(1)$. This means that the bound co-integration testing procedure does not require the pre-testing of the variables included in the model for unit roots and is robust when there is a single long run relationship between the underlying variables,

- If the F-statistics (Wald test) establishes that there is a single long run relationship and the sample data size is small or finite, the ARDL error correction representation becomes relatively more efficient.

- If the F-statistics (Wald test) establishes that there are multiple long-run relations, ARDL approach cannot be applied. Hence, an alternative approach like Johansen and Juselius [14] can be applied. That is, if the various single expression/equation of the underlying individual variable as dependent variable shows a feedback effect (multiple long run relationships) between the variables, then a multivariate procedure needs to be employed.

- If the trace or Maximal eigenvalue or the Fstatistics establishes that there is a single long- 
run relationship, ARDL approach can be applied rather than applying Johansen and Juselius approach.

\subsection{Estimation and Specification}

According to Pesaran et al. [10], the error correction model of the ARDL model is:

$$
\begin{gathered}
\Delta I N F_{t}=\alpha_{0}+\sum_{i=1}^{p} \alpha_{1 i} \Delta I N F_{t-i}+\sum_{i=0}^{q 1} \alpha_{2 i} \Delta E R_{t-i}+\sum_{i=0}^{q 2} \alpha_{3 i} \Delta M G_{t-i}+\sum_{i=0}^{q 3} \alpha_{4 i} \Delta G D P_{t-i}+ \\
\sum_{i=0}^{q 4} \alpha_{5 i} \Delta O E_{t-i}+\beta_{1} I N F_{t-1}+\beta_{2} E R_{t-1}+\beta_{3} M G_{t-1}+\beta_{4} G D P_{t-1}+\beta_{5} O E_{t-1}+\varepsilon_{t}
\end{gathered}
$$

The null hypothesis of no cointegration is $H_{0}: \beta_{1}=$ $\cdots=\beta_{5}=0$, and the alternative hypothesis that cointegration exists is: $\mathrm{H}_{1}$ : at least one parameter not equal to zero, it's achieved by Wald test using F-test. The null hypothesis can be rejected, when the value of F-statistic is greater than the upper bound critical value. Since there is a long-run relationship, then the conditional autoregressive distributed lag model will be conducted that can be used to estimate the long-run coefficient. The second step in the second stage of the bounds testing ARDL method involves approximating a restricted ECM. A principle feature of cointegrated variables is that their time paths are influenced by the extent of any deviation from long-run symmetry. After all, if the system is to return to long-run equilibrium, the movements of at least some of the variables must respond to the magnitude of disequilibrium [24]. The following equation specifies the conditional ECM:

$$
\begin{gathered}
\Delta I N F_{t}=\alpha_{0}+\sum_{i=1}^{p} \alpha_{1 i} \Delta I N F_{t-i}+\sum_{i=0}^{q 1} \alpha_{2 i} \Delta E R_{t-i}+\sum_{i=0}^{q 2} \alpha_{3 i} \Delta M G_{t-i}+\sum_{i=0}^{q 3} \alpha_{4 i} \Delta G D P_{t-i}+ \\
\sum_{i=0}^{q 4} \alpha_{5 i} \Delta O E_{t-i}+v E C T_{t-1}+\varepsilon_{t}
\end{gathered}
$$

where ECT is known as Error Correction Term which indicate that the speed of adjustment parameter, the ECT shows how much of the disequilibrium is being corrected, that is, the extent to which any disequilibrium in the previous period is being adjusted in current point.

\section{Empirical Application}

\subsection{Descriptive Statistics}

Some descriptive statistics of the variables are presented in Table 1. The main result from these statistics is the all variables (except ER) are normally distributed because the p-value of JarqueBera [25] test of each variable more than 0.05 , then we can't reject the null hypothesis, where the null hypothesis of Jarque-Bera test is the data is normally distributed.

Figure 1 shows that INF and MG are not have a linear trend, but ER, GDP, and OE have a linear trend. This means that most these variables are not stationarity, and then we should take the first difference to them.

For testing the stationarity of the variables, Augmented Dickey-Fuller (ADF) [26] test has been used. The null hypothesis $\left(\mathrm{H}_{0}\right)$ of the ADF test is "series has a unit root" versus the alternative hypothesis $\left(\mathrm{H}_{1}\right)$ which is "the series is stationary". If the p-value less than 0.05 , we can reject $\mathrm{H}_{0}$, then the variable is stationarity. Table 2 indicates that the ADF test confirmed that all variables are stationary at I(1) (integrated of order 1), except MG variable is stationary at $\mathrm{I}(0)$ (stationary at the level).

Table 1. Descriptive statistics of the variables from 2005:Q1 to 2019:Q4

\begin{tabular}{|l|c|r|r|r|r|r|r|r|}
\hline \multirow{2}{*}{ Variable } & Abbreviation & \multirow{2}{*}{ Min. } & Mean & \multirow{2}{*}{ Median } & \multirow{2}{*}{ SD } & \multirow{2}{*}{ Max. } & \multicolumn{2}{c|}{ Jarque-Bera test } \\
\cline { 7 - 10 } & & & & & & & & \\
& INF & -3.73 & 10.84 & 11.07 & 5.78 & 24.30 & 0.27 & 0.88 \\
\hline Inflation CPI & ER & 118.82 & 210.68 & 161.65 & 94.44 & 397.24 & 10.52 & 0.01 \\
\hline Exchange Rate & GDP & 22.16 & 24.72 & 24.72 & 1.44 & 26.96 & 2.52 & 0.28 \\
\hline $\begin{array}{l}\text { Gross Domestic } \\
\text { Product }\end{array}$ & MG & -12.66 & 19.90 & 15.81 & 14.89 & 55.66 & 2.75 & 0.25 \\
\hline Money Growth & OE & 1.18 & 1.72 & 1.71 & 0.21 & 2.20 & 1.11 & 0.57 \\
\hline Oil Export & &
\end{tabular}


Table 2. Results of ADF test

\begin{tabular}{|l|c|c|c|c|c|}
\hline \multirow{2}{*}{ Variable } & \multicolumn{2}{|c|}{ Level } & \multicolumn{2}{c|}{ First difference } & Integration degree \\
\cline { 2 - 5 } & t-statistic & p-value & t-statistic & p-value & \\
\hline INF & -2.606644 & 0.0978 & -4.779701 & 0.0003 & $\mathrm{I}(1)$ \\
\hline ER & -1.619991 & 0.7729 & -10.02139 & 0.0000 & $\mathrm{I}(1)$ \\
\hline GDP & -3.162854 & 0.1033 & -7.803901 & 0.0000 & $\mathrm{I}(1)$ \\
\hline MG & -6.090620 & 0.0000 & ------- & ------- & $\mathrm{I}(0)$ \\
\hline OE & -2.042594 & 0.2684 & -2.964642 & 0.0456 & $\mathrm{I}(1)$ \\
\hline
\end{tabular}

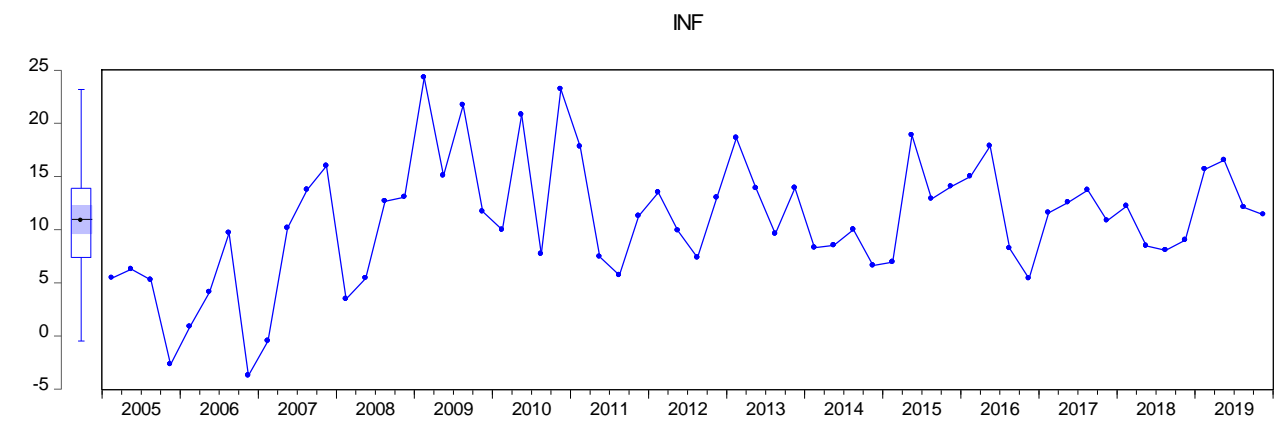

ER

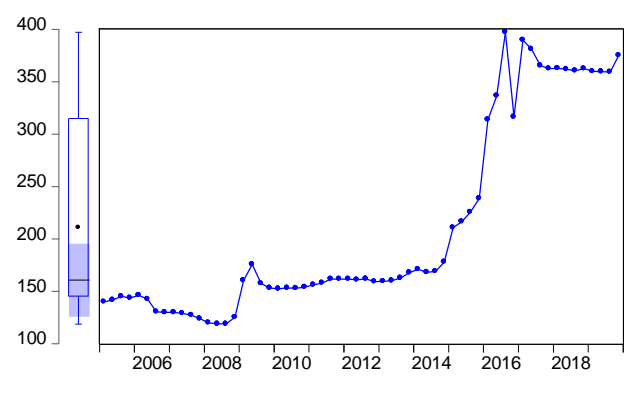

MG

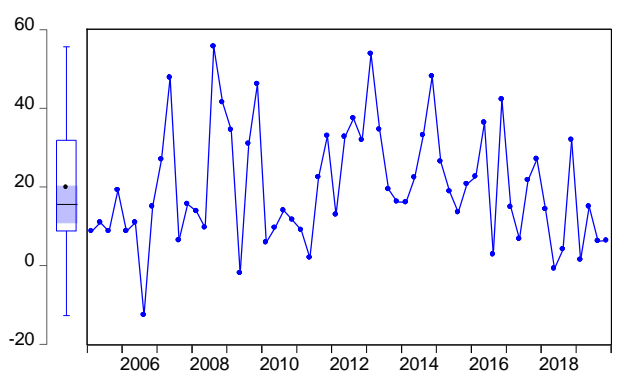

GDP

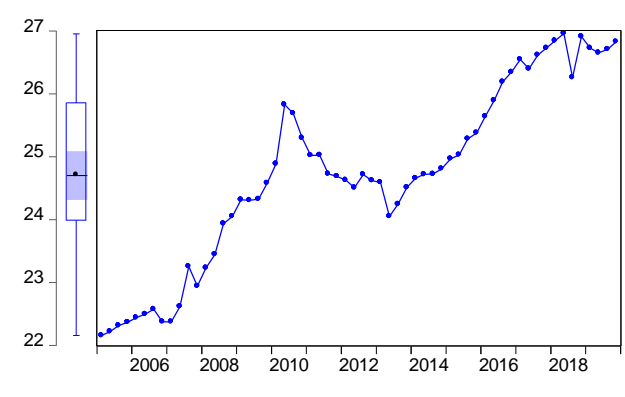

$\mathrm{OE}$

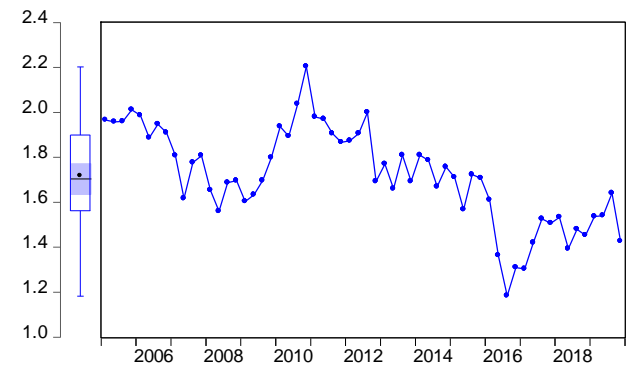

Fig. 1: Time series plots of the variables from 2005:Q1 to 2019:Q4

\subsection{ARDL Model}

The estimated ARDL model with automatic lag selection using E-views (version 10) is $\operatorname{ARDL}(1,1$,
$0,2,0)$ model, it was selected depending on the least AIC, as shown in Figure 2. 
Table 3 shows that there are significant effects of the lags of INF, ER, and MG variables on current Inflation rate. However, GDP and OE have not lag effect on current Inflation rate. All estimated coefficients of the model are highly statistically significant at 0.01 (level of significant), except the coefficient of $\mathrm{OE}$ is not significant. Since the pvalue of F-statistic less than 0.01 , then the model overall is highly statistically significant.

\subsection{Bounds F-Test}

As stated before the bounds test is the test to find out if there is a long-run relationship as a null hypothesis says that; there is no long-run relationship, conferring to the value of F-statistics, first case; if this value lower than I(0) we don't reject the null hypothesis and there is no long rum relationship, second; if this value greater than I(1) we reject the null hypothesis and we can indicate that there is long relationship, the last case; if this value lies between two bounds we cannot conclude. Here, we are in second case as the value of Fstatistic (12.283) greater that upper bound which include that there is a long-run relationship for all levels of significance more than or equal to $1 \%$ as shown in Table 4.

Fig. 2: Model Selection Summary Graph

Akaike Information Criteria (top 20 models)

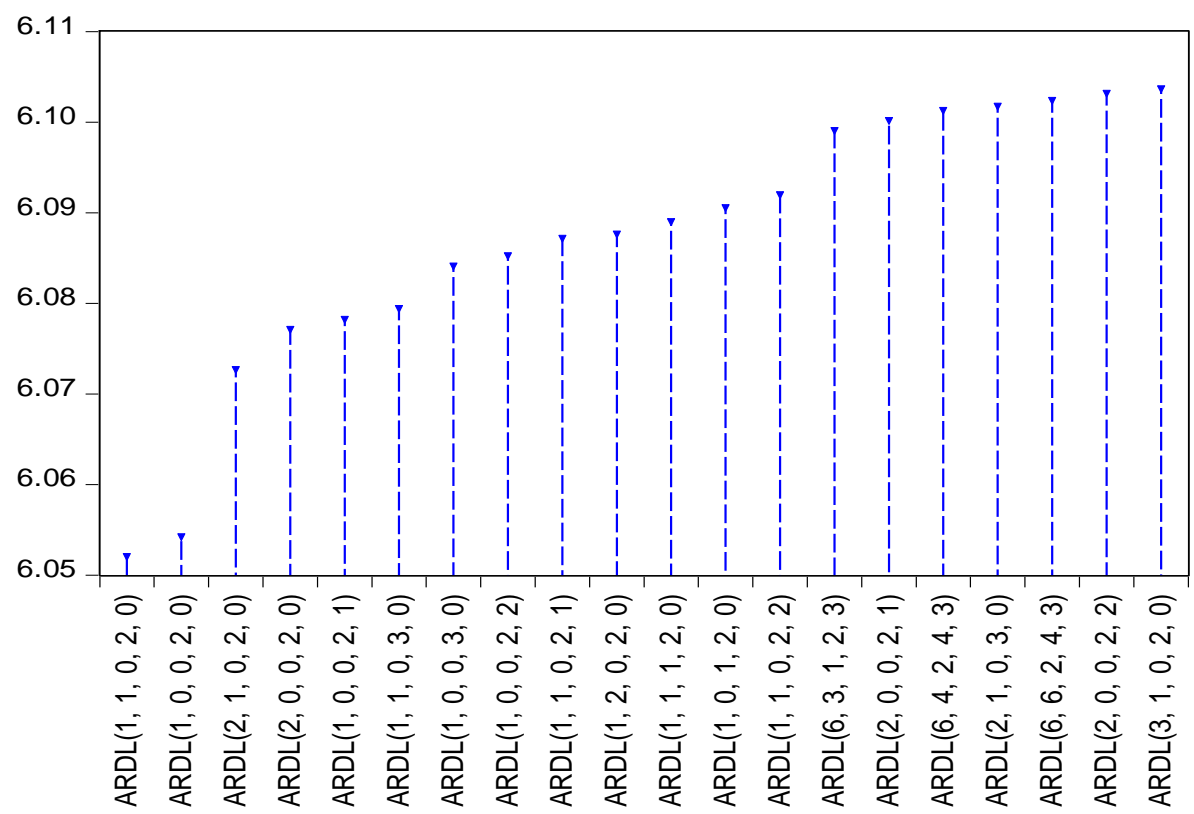

Table 3. The results of ARDL $(1,1,0,2,0)$ model

\begin{tabular}{|l|r|r|r|r|}
\hline Variable & Coefficient & Std. Error & t-Statistic & P-value \\
\hline Constant & -56.00316 & 1.466525 & -38.18765 & 0.0001 \\
\hline INF(-1) & 0.114846 & 0.008754 & 13.11935 & 0.0001 \\
\hline ER & 0.031939 & 0.002503 & 12.75991 & 0.0001 \\
\hline ER(-1) & -0.054124 & 0.002367 & -22.86540 & 0.0001 \\
\hline GDP & 2.601982 & 0.071003 & 36.64601 & 0.0001 \\
\hline MG & 0.053901 & 0.003312 & 16.27465 & 0.0001 \\
\hline MG(-1) & 0.016447 & 0.003401 & 4.835552 & 0.0001 \\
\hline MG(-2) & 0.161413 & 0.003237 & 49.86478 & 0.0001 \\
\hline OE & 0.588073 & 0.382397 & 1.537860 & 0.1241 \\
\hline \multicolumn{5}{|r}{ Model Statistics } \\
\hline
\end{tabular}




\begin{tabular}{|l|r|l|r|}
\hline R-squared & 0.467063 & Adjusted R-squared & 0.380053 \\
\hline F-statistic & 5.367915 & P-value (F-statistic) & 0.0001 \\
\hline
\end{tabular}

Table 4. F-Bounds Test Results

\begin{tabular}{|l|c|r|r|r|}
\hline Test Statistic & Value & Significant level & I(0) & I(1) \\
\hline & & & Asymptotic: $\mathrm{n}=1000$ & \\
\hline F-statistic & $\mathbf{1 2 . 2 8 3}$ & $10 \%$ & 2.45 & 3.52 \\
\hline $\mathrm{k}$ & 4 & $5 \%$ & 2.86 & 4.01 \\
\hline & & $2.5 \%$ & 3.25 & 4.49 \\
\hline & & $1 \%$ & 3.74 & 5.06 \\
\hline Actual Sample Size & 58 & & Finite Sample: $\mathrm{n}=60$ & \\
\hline & & $10 \%$ & 2.568 & 3.712 \\
\hline & & $\mathbf{5 \%}$ & $\mathbf{3 . 0 6 2}$ & $\mathbf{4 . 3 1 4}$ \\
\hline & & $1 \%$ & 4.176 & 5.676 \\
\hline & & & Finite Sample: $\mathrm{n}=55$ & \\
\hline & & $10 \%$ & 2.578 & 3.71 \\
\hline & & $\mathbf{5 \%}$ & $\mathbf{3 . 0 6 8}$ & $\mathbf{4 . 3 3 4}$ \\
\hline & & $1 \%$ & 4.244 & 5.726 \\
\hline
\end{tabular}

\subsection{Error Correction Model}

Since there is a cointegration (long-run) relationship, the error correction model is performed. Table 5 shows that the change (difference) of ER and MG is highly statistically significant (at 0.01) on the change of the INF. Moreover, the ECT is negative sign and highly significant which indicate convergence, and we can conclude that the adjustment is taken place after two quarters only of the year.

\subsection{Diagnostics Tests}

For the estimated model, we performed four diagnostics tests: stability, normally, serial correlation, and heteroskedasticity [5].

For testing the normality of residuals, Jarque-Bera [25] test is used as in [27, 28]. According to this test, the null hypothesis is the residuals are normally distributed. Then if $\mathrm{p}$-value of Jarque-Bera test more than 0.05 , then we can accept the null hypothesis. Figure 3 shows that the residuals of the model are normally distributed, because the p-value of the test statistic is more than 0.05 .

For testing the serial correlation and heteroskedasticity of the errors, Breusch-Godfrey LM and Breusch-Pagan-Godfrey tests have been performed. The results of Table 6 confirmed that there is no longer serial correlation between errors, and the errors of the model have constant variance (i.e., no heteroskedasticity), because P-values of the two tests $(0.5423$ and 0.4575$)$ more than 0.05 , this means that we don't reject the null hypotheses of the two tests at level 0.05 .

Table 5. The results Error Correction Model

\begin{tabular}{|l|l|l|l|l|}
\hline Variable & Coefficient & Std. Error & t-Statistic & P-value \\
\hline Constant & -62.24456 & 0.251289 & -247.7008 & 0.0001 \\
\hline D(ER) & 0.036089 & 0.000975 & 37.02351 & 0.0001 \\
\hline D(MG) & 0.045281 & 0.001101 & 41.11903 & 0.0001 \\
\hline D(MG(-1)) & -0.144711 & 0.001180 & -122.6092 & 0.0001 \\
\hline EC(-1) & -0.896819 & 0.003614 & -248.1318 & 0.0001 \\
\hline \multicolumn{5}{|c|}{ Model Statistics } \\
\hline R-squared & 0.561189 & Adjusted R-squared & 0.528071 \\
\hline
\end{tabular}




\begin{tabular}{|l|l|l|l|}
\hline F-statistic & 16.94523 & P-value of F-statistic & 0.0001 \\
\hline
\end{tabular}

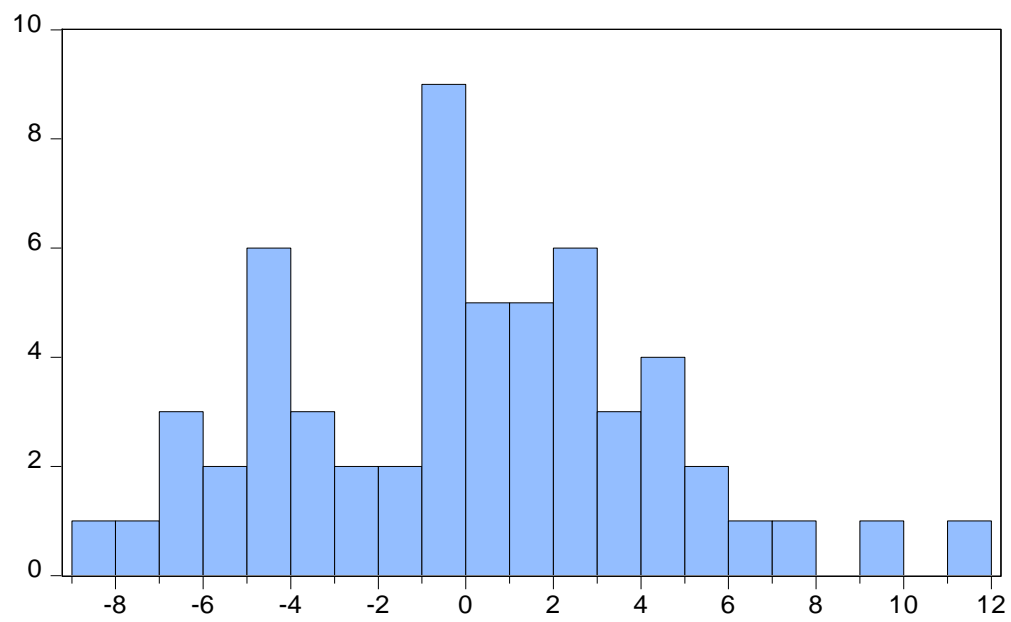

\begin{tabular}{|lr|}
\hline \multicolumn{2}{|l|}{ Series: Residuals } \\
Sample 2005Q3 2019Q4 \\
Observations 58 \\
Mean & $2.63 \mathrm{e}-15$ \\
Median & -0.014631 \\
Maximum & 11.18216 \\
Minimum & -8.110800 \\
Std. Dev. & 4.232918 \\
Skewness & 0.189766 \\
Kurtosis & 2.757253 \\
& \\
Jarque-Bera & 0.490513 \\
p-value & 0.782504 \\
\hline
\end{tabular}

Fig. 3: Histogram and Jarque-Bera test of the residuals

Table 6. Serial Correlation and Heteroskedasticity tests

\begin{tabular}{|l|c|l|}
\hline \multicolumn{1}{|c|}{ Test } & \multicolumn{1}{|c|}{$\boldsymbol{\chi}^{\mathbf{2}}$} & P-value \\
\hline Breusch-Godfrey Serial Correlation LM Test & 1.223936 & 0.5423 \\
\hline Breusch-Pagan-Godfrey Heteroskedasticity test & 7.757494 & 0.4575 \\
\hline
\end{tabular}

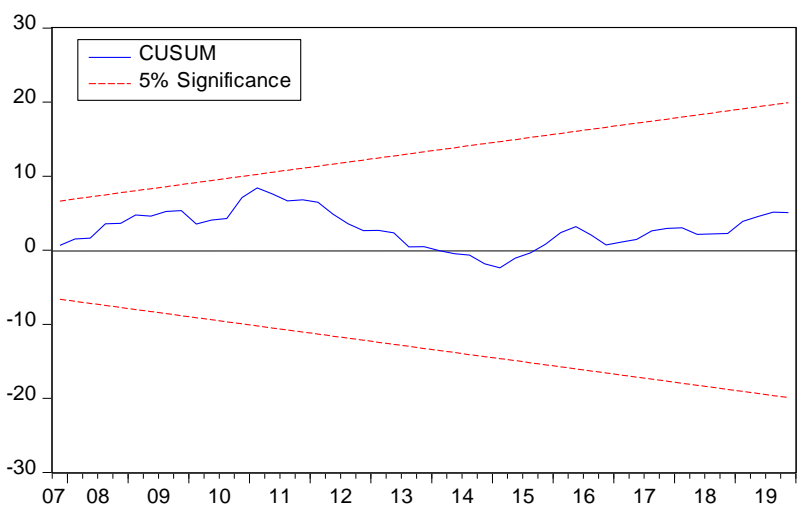

Fig. 4: CUSUM (Stability) test of the model

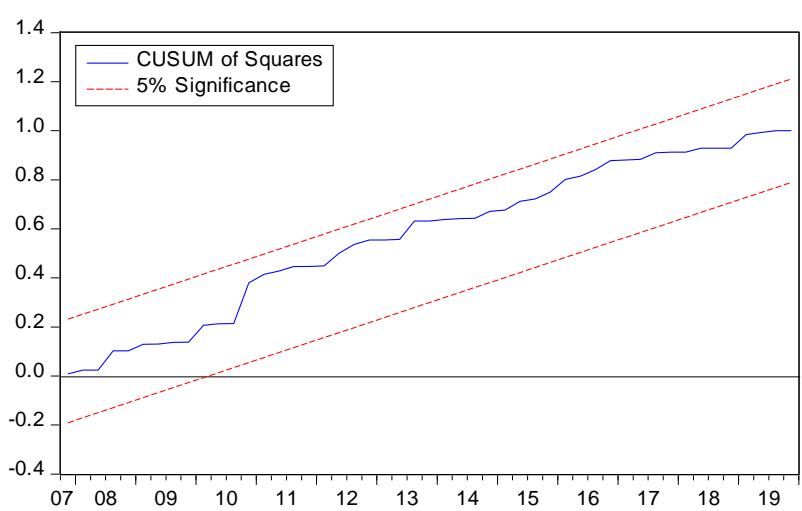

Fig. 5: CUSUM of squares (Stability) test of the model
For checking the stability and the accuracy of the estimated model, the cumulative sum of the recursive residuals (CUSUM) and CUSUM of squares are used, see Figures 4 and 5. These figures of the stability are confirmed that the estimated model satisfies the stability condition during the sample period, because the CUSUM and CUSUM of squares are within the 5\% significance lines.

\section{Conclusion}

This study presents the most recent and very effective approach to modeling dynamic systems using an autoregressive distributed lag (ARDL) model by applying it to Nigeria's inflation rate. The model succeeded in tackling the problem of mixedstationary and non-stationary series as they can be treated with series that integrated from different orders and overcame the problem of serial correlation associated with the least square regression method. We discovered that in the long run, the Nigerian inflation would have a long-run equilibrium relationship with exchange rate and money growth, and the best ARDL model describing this relationship is $\operatorname{ARDL}(1,1,0,2,0)$. The results indicate that the current values of the exchange rate, GDP, money growth, and lagged values of the inflation rate, exchange rate, and 
money growth significantly affect the current inflation rate. But the oil export has no significant effect on the inflation rate. Moreover, a cointegration (long-run) relation-ship between these variables also concludes that $90 \%$ of the short-run adjustment to the long-run takes place each quarter.

\section{References:}

[1] Folorunso, B. A. and Abiola, A. G. (2000). The long-run determinants of inflation in Nigeria, 1970-1998. Nigerian Journal of Economic and Social Statistics, 42(1), 37-53.

[2] Taiwo, J. K. (2011). Econometric Analysis of the Causes and Effects of Inflation, M.Sc. Thesis, Department of Mathematics, University of Abuja, Nigeria.

[3] Aminu, U. \& Anono, A. Z. (2012). An empirical analysis of the relationship between unemployment and inflation in Nigeria: 1977-2009. Business Journal, Economics and Review, 1(12), 42-61.

[4] Eze, O. M., \& Nweke, A. M. (2017). Assessment of the Effect of Inflation on Nigeria's Economic Growth: Vector Error Correction Model Approach. European Journal of Business and Management, 9(15), 18-29.

[5] Abonazel, M. R. and Elnabawy, N. (2020). Using the ARDL bound testing approach to study the inflation rate in Egypt. Economic consultant, 31 (3), 24-41.

[6] Orubu, C. O. (2009). Inflation in Nigeria: Concept, measurement and control. Central Bank of Nigeria (CBN) Bullion, 33(1), 1930.

[7] Greene, William. H. (2008). Econometric analysis, 7th edition. Prentice Hall.

[8] El-Sheikh, A.A., Alteer, F.A. and Abonazel, M.R., 2021. Four imputation methods for handling missing values in the ARDL model: An application on Libyan FDI. Journal of Applied Probability \& Statistics, Accepted Paper 2021.

[9] Pesaran, M. H. and Shin, Y. (1999). An Autoregressive Distributed Lag Modeling Approach to Cointegration Analysis, In: Strom, S., Holly, A., Diamond, P. (Eds.). Centennial Volume of Rangar Frisch, Cambridge University Press, Cambridge.

[10] Pesaran, M. H., Shin, Y. and Smith, R.J. (2001). Bounds testing approaches to the analysis of level of relationship. Journal of Applied Econometrics, 16 (3), 289-326.
[11] Emeka, N., Kelvin U. (2016). Autoregressive Distributed Lag (ARDL) cointegration technique: application and interpretation. Journal of Statistical and Econometric Methods, 5 (4), 63-91.

[12] Engle, R. and Granger, G. (1987). Cointegration and error correction: representation, estimation and testing. Econometrica, 55, 251-276.

[13] Johansen, S. (1988). Statistical analysis of cointegrating vectors. Journal of Economic Dynamic and Control, 12, 231-54.

[14] Johansen, S. and Juselius, K. (1990). Maximum likelihood estimation and inference in cointegration - with application to the demand for money. Oxford Bulletin of Economics and Statistics, 52 (2), 169210.

[15] Saikkonen, P. and H. Lütkepohl. (2000). Testing for cointegrating rank of a VAR process with an intercept. Econometric Theory, 16 (3), 373-406.

[16] Ghouse, G., Khan,S.A., and Rehman,A.U. (2018). ARDL model as a remedy for spurious regression: problems, performance and prospectus. Pakistan Institute of Development Economics. Available at: https://mpra.ub.uni-muenchen.de/83973/.

[17] Ghavam, Masoodi, Z. and Tashkini, A. (2005). The Empirical Analysis of Inflation in Iran. Quarterly Business Research Letter, $36,75-105$.

[18] Tian, G. G., and Ma, S. (2010). The relationship between stock returns and the foreign exchange rate: The ARDL approach. Journal of the Asia Pacific Economy, $15 \quad$ (4), 490-508. DOI: $10.1080 / 13547860.2010 .516171$

[19] Chaudhry, M.I., Akhtar, M.H. and Mahmood, K. (2011). Foreign exchange reserves and inflation in Pakistan: evidence from ARDL modelling approach. International Journal of Economics and Finance, 3 (1), 69-76.

[20] Chou, K.W. and Tseng, Y.H. (2011). Passthrough of oil prices to CPI inflation in Taiwa. International Research Journal of Finance and Economics, 6 (9), 73-83.

[21] Tzu-Kuang Hsu, I-Hsun Tsai, The Effect of Tourism Development on Economic Growth in Taiwan: Export Growth as Mediator, International journal of circuits, systems and signal processing, Volume 14, 2020, pp. 435-439. 
[22] Ajayi, S. I. (1978). Money in a developing economy: A portfolio approach to money supply determination in Nigeria. Ibadan University Press.

[23] Hill, R. C., Griffiths, W. E. and Lim, G. C. (2012), Principles of Econometrics, John Wiley and Sons.

[24] Enders, W. (2004). Applied econometric time series, 2nd edition. New Jersey, John Wiley and Sons.

[25] Jarque, C. M., \& Bera, A. K. (1980). Efficient tests for normality, homoscedasticity and serial independence of regression residuals. Economics letters, 6(3), 255-259.

[26] Dickey, D., and Fuller, W. (1981). Likelihood Ratio Tests for Autoregressive Time Series with a Unit Root, Econometrica, 49, 1057-1072.

[27] Abonazel, M. R., \& Abd-Elftah, A. I. (2019). Forecasting Egyptian GDP using ARIMA models. Reports on Economics and Finance, 5(1), 35-47.

[28] Abonazel, M., \& Rabie, A. (2019). The impact of using robust estimations in regression models: An application on the Egyptian economy. Journal of Advanced Research in Applied Mathematics and Statistics, 4(2), 8-16.
Creative Commons Attribution License 4.0 (Attribution 4.0 International, CC BY 4.0)

This article is published under the terms of the Creative Commons Attribution License 4.0

https://creativecommons.org/licenses/by/4.0/deed.en _US 